\title{
Molecular characterization, purification, and antioxidant activity of recombinant superoxide dismutase from the Pacific abalone Haliotis discus hannai Ino
}

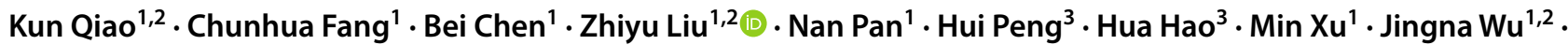 \\ Shuji Liu ${ }^{1}$
}

Received: 20 October 2019 / Accepted: 7 July 2020 / Published online: 14 July 2020

(C) The Author(s) 2020

\begin{abstract}
Superoxide dismutase (SOD) is an acidic metalloenzyme that scavenges free radicals produced by endogenous and exogenous substances. In the present study, the tissue distribution of the superoxide dismutase $\mathrm{HdhCu} / \mathrm{Zn}$-SOD was investigated in Haliotis discus hannai Ino. The expression profile after lipopolysaccharide (LPS) challenge was determined using quantitative real-time polymerase chain reaction (qPCR). To study the antioxidant activity of a recombinant $\mathrm{HdhCu} / \mathrm{Zn}-\mathrm{SOD}$ protein, the $\mathrm{HdhCu} / \mathrm{Zn}$-SOD gene was cloned into the pPIC9K vector and transformed into the Pichia pastoris GS115 strain by electroporation. After induction by methanol, the recombinant product was purified using immobilized metal affinity chromatography and confirmed using mass spectrometry. The optimal expression conditions were determined to be incubation with $0.5 \%$ methanol at $\mathrm{pH} 6.0$, resulting in a stable expressed product with the molecular weight of approximately $17 \mathrm{kDa}$ and $21 \mathrm{kDa}$. The enzymatic activity of $\mathrm{HdhCu} / \mathrm{Zn}-\mathrm{SOD}$ consistently increased with increasing $\mathrm{Cu}^{2+}$ concentrations and showed good thermal stability. Recombinant $\mathrm{HdhCu} / \mathrm{Zn}$-SOD showed a strong ability to scavenge superoxide anions and hydroxyl radicals and protected L929 cells against the toxicity caused by $\mathrm{H}_{2} \mathrm{O}_{2}$ through its in vitro antioxidant activity. The heterologous expression of $\mathrm{HdhCu} / \mathrm{Zn}-\mathrm{SOD}$ in $P$. pastoris and the antioxidant activity of this enzyme are reported for the first time.
\end{abstract}

Electronic supplementary material The online version of this article (https://doi.org/10.1007/s11274-020-02892-5) contains supplementary material, which is available to authorized users.

Zhiyu Liu

13906008638@163.com

1 Fisheries Research Institute of Fujian, Key Laboratory of Cultivation and High-Value Utilization of Marine

Organisms in Fujian Province, Xiamen 361013, China

2 The Public Service Platform for Industrialization Development Technology of Marine Biological Medicine and Product of State Oceanic Administration, Fuzhou 350117, China

3 College of Ocean and Earth Sciences, Xiamen University, Xiamen 361013, China 


\section{Graphic abstract}

\section{Purification and antioxidant activity of recombinant superoxide dismutase}

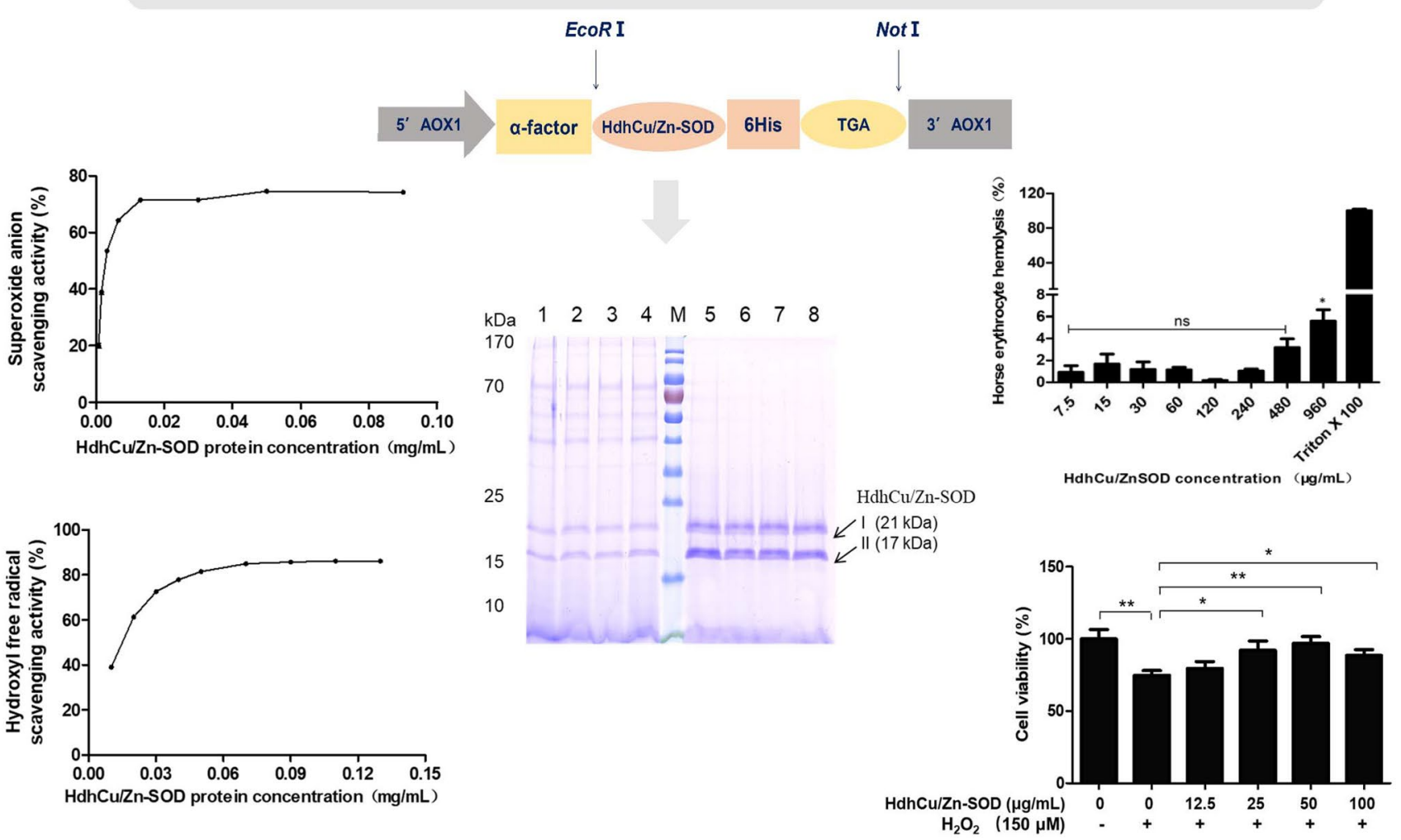

Keyword Antioxidant $\cdot$ Haliotis discus hannai $\cdot$ Pichia pastoris $\cdot$ Superoxide dismutase

$\begin{array}{lll}\begin{array}{l}\text { Abbreviations } \\ \text { BMGY }\end{array} & \begin{array}{l}\text { Buffered glycerol-complex } \\ \text { medium } \\ \text { Buffered methanol-complex } \\ \text { medium }\end{array} & \\ \text { BMMY } & \text { Complementary DNA } & \text { Ni-SOD } \\ \text { cDNA } & \text { ORF } \\ \mathrm{Cu} / \mathrm{Zn} \text {-SOD } & \text { Iron SOD } & \text { PBS } \\ \mathrm{Fe}-\mathrm{SOD} & \begin{array}{l}\text { Glutathione } \\ \text { GSH }\end{array} & \text { PCR } \\ \mathrm{H}_{2} \mathrm{O}_{2} & \begin{array}{l}\text { Hydrogen peroxide } \\ \text { LPS }\end{array} & \text { ROS } \\ \text { MALDI-TOF/TOF-MS } & \begin{array}{l}\text { Matrix assisted laser desorption/ } \\ \text { ionization time-of- flight/time- } \\ \text { of- flight mass spectrometry }\end{array} & \text { SOD } \\ & \text { Minimal dextrose } & \text { YPD } \\ \text { MD } & \text { Manganese SOD } & \\ \text { Mn-SOD } & & \end{array}$

3-(4,5-Dimethylthiazol-2-yl)5-(3-carboxymethoxyphenyl)2-(4-sulfophenyl)-2H-tetrazolium/ phenazine methosulfate Nickel-containing SOD Open reading frame Phosphate buffer saline Polymerase chain reaction Reactive oxygen species Sodium dodecyl sulphate polyacrylamide gel electrophoresis Superoxide dismutase Yeast nitrogen base Yeast extract peptone dextrose medium 


\section{Introduction}

Marine organisms exposed to a complex aquatic environment show increased antioxidant responses. Reactive oxygen species (ROS) are oxygen free radicals that are generated during aerobic cellular metabolism, such as superoxide anions $\left(\mathrm{O}_{2^{-}}\right)$, hydroxyl radicals $(. \mathrm{OH})$, single oxygen $\left(. \mathrm{O}_{2}\right)$, and hydrogen peroxide $\left(\mathrm{H}_{2} \mathrm{O}_{2}\right)$ (Genestra 2007). In organisms, ROS remain in dynamic equilibrium under normal physiological conditions (Finkel and Holbrook 2000). Under inflammation, the oxidase enzyme is activated in host organisms, leading to the production of ROS that kill invading pathogens (known as respiratory burst Hsieh et al. 2008;). However, many types of environmental stimuli, including ultraviolet light, environmental toxins, and hyperthermia, generate high levels of ROS, resulting in cellular oxidative damage. ROS can degrade unsaturated fatty acids on the cell membrane and destroy the membrane structure (Sargis and Subbaiah 2006), leading to the cleavage of polypeptide chains (Stadtman and Levine 2003) and the formation of single-strand breaks in nuclear DNA (Melidou et al. 2005). To avoid cellular oxidative damage and prevent disease and death caused by oxidative stress, marine organisms develop an effective defense system to maintain the balance of ROS. The antioxidant system of mollusks includes enzymatic antioxidants such as superoxide dismutase (SOD, EC1.15.1.1), catalase, thioredoxin peroxidase, glutathione peroxidase, and glutathione-S-transferase and nonenzymatic antioxidants such as selenium-binding protein, metallothionein, thioredoxin, ferritin, and transferrin.

Superoxide dismutase is an acidic metalloenzyme that is ubiquitous in animals, plants, and microorganisms. In vivo, its role is to scavenge free radicals produced by endogenous and exogenous substances, inhibit lipid peroxidation, and delay senescence to protect the organism (Che et al. 2016; Fukai and Ushio-Fukai, 2011). SOD can also improve phagocytosis and viral resistance in cells and is therefore often used as a potential marker for the assessment of environmental stress and water pollution (Achuba 2002; Penicaud et al. 2017; Ren et al. 2017). SODs are mainly divided into three types depending on their metal co-factor: iron SOD (Fe-SOD), manganese SOD (MnSOD) and copper and zinc SOD (Cu/Zn-SOD) (Smith et al. 2003; Wu et al. 2008). Cu/Zn-SOD can be further divided into extracellular $\mathrm{Cu} / \mathrm{Zn}$-SODs, with an N-terminal signal sequence, and intracellular $\mathrm{Cu} / \mathrm{Zn}-\mathrm{SODs}$, without an N-terminal signal sequence (Lin et al. 2008). SODs can be divided into two main families based on their structure, one of which consists of $\mathrm{Cu} / \mathrm{Zn}$-SODs, while the other family comprises Fe-SODs and Mn-SODs (Lin et al. 2008). There are more available data and in-depth mechanistic studies on $\mathrm{Cu} / \mathrm{Zn}$-SODs than the other types. Researchers have also discovered rare SOD types such as a nickel-containing SOD (Ni-SOD) and an iron and zinccontaining SOD that is similar to Fe-SOD (Fe/Zn-SOD) in Streptomyces (Hong-Duk et al. 1996; Kim et al. 1996).

The Pacific abalone (Haliotis discus hannai Ino) is an economically important species in mariculture in China. Recently, the effects of water quality on mariculture in oceans and self-degradation of cultivated abalones have reduced disease resistance in artificially cultivated abalones. The antioxidant defense system plays an important role in defense and protection by ensuring the synthesis of protective ROS and preventing damage to the body. As the first-line enzymatic defense against superoxide, SOD scavenges free radical species produced from endogenous and exogenous substances. However, few studies have evaluated the detailed structure and protein function of antioxidant enzymes in marine invertebrates. These studies mainly involve cloning of antioxidant genes, genetic structure analyses, phylogenetic analyses, differential expression analyses, and in vitro prokaryotic expression of recombinant proteins, whereas there are fewer studies on functional validation at the protein level (Bao et al. 2008, 2009a, b; Han et al. 2016; Kim et al. 2011; Zheng et al. 2015). In order to gain insight into the innate immune defense mechanisms of abalones, we studied the expression characteristics of the SOD gene, which is the first line of defense against ROS. In this study, the tissue distribution of $\mathrm{HdhCu} / \mathrm{Zn}-\mathrm{SOD}$ was investigated in $H$. discus hannai Ino. To evaluate whether the $\mathrm{HdhCu} /$ Zn-SOD gene responds to immune-stimulant challenges, the expression profile after lipopolysaccharide (LPS) challenge was determined by quantitative real-time polymerase chain reaction (qPCR). Furthermore, we constructed a eukaryotic expression vector, $\mathrm{pPIC} 9 \mathrm{~K}-\mathrm{HdhCu} / \mathrm{Zn}-\mathrm{SOD}$, and induced the expression of this recombinant protein in the Pichia pastoris GS115 strain. The recombinant protein was purified by affinity chromatography, followed by antioxidant and cellular safety evaluation of the purified product. Study on the protective role of this recombinant protein against hydrogen peroxide-induced cell damage will develop its application in cosmetics, medicine, and other products as an additive.

\section{Materials and methods}

\section{Animals and tissue collection}

Pacific abalones (H. discus hannai) were purchased from the Dongshan abalone farm in Fujian Province and acclimatized in a laboratory environment for 7 days before the experiments were carried out. The animals were reared in $80 \mathrm{~L}$ polyvinyl chloride tanks containing $40 \mathrm{~L}$ of natural seawater, which was purified through a biofilter and renewed 
daily to ensure water quality. The animals were fed with the marine alga Gracilaria tenuistipitata during the acclimation and experimental period.

The abalones were divided into saline and LPS groups. LPS from E. coli (L2880, Sigma, USA) was dissolved in saline to $1 \mathrm{mg} / \mathrm{mL}$ for animal challenge. The abalones were injected with $50 \mu \mathrm{L}$ of LPS or an equal volume of sterile saline via the front of the foot. The injection method was based on a previously published paper (Huang et al. 2010; Ren et al. 2009). Normal Pacific abalones were used as controls. Abalone hemocyte, gill, hepatopancreas, gonad, mantle, digestive gland, shell muscle, and epipodium samples were collected at $0,4,8,12,24,48$, and $96 \mathrm{~h}$ after injection. Samples from five abalones were collected from each group as parallel samples. The samples were rapidly placed in liquid nitrogen and stored at $-80^{\circ} \mathrm{C}$.

\section{Real-time PCR quantitation of $\mathrm{HdhCu} / \mathrm{Zn}$-SOD expression in Pacific abalones}

The Trizol reagent was used to extract total RNA from the collected samples as previously described (Qiao et al. 2016; Liu et al. 2010). cDNA synthesis was carried out using the PrimeScript ${ }^{\mathrm{TM}} \mathrm{RT}$ reagent kit (Perfect Real Time) (TaKaRa), following the manufacturer's instructions. The $\mathrm{HdhCu} / \mathrm{Zn}$ SOD sequence was obtained from a transcriptome library in our previous study (GenBank accession no. KX302627). The real-time PCR system had a volume of $20 \mu \mathrm{L}$ and included $10 \mathrm{ng}$ of total RNA, $10 \mathrm{pmol}$ of the specific primers $\mathrm{HdhCu} / \mathrm{Zn}$-SOD QS2 (5'-CAGTTCGGGGACAACACC AA-3') and HdhCu/Zn-SOD QA2 (5'-TGTTTGCTACTC CTGATGCGT-3'), and $10 \mu \mathrm{L}$ of FastStart Universal SYBR Green Master (Rox) (Roche). The reaction conditions were as follows: preincubation at $95^{\circ} \mathrm{C}$ for $600 \mathrm{~s}$, followed by 45 cycles (denaturation, $95^{\circ} \mathrm{C}$ for $10 \mathrm{~s}$; annealing, $60^{\circ} \mathrm{C}$ for $10 \mathrm{~s}$; and extension at $72{ }^{\circ} \mathrm{C}$ for $10 \mathrm{~s}$ ). The $\beta$-actin (GenBank accession no. MN123625, $\beta$-actin QS2: 5'-TCTGCTACA TCGCCCTTGAC-3'; $\beta$-actin QA2: 5'-AGGGACTCTGGA CAACGGAA-3') and Ribosomal protein L7 primers (GenBank accession no. KP698945, 7RPL-FW: 5'- CAAGCT GAACACTCCAAACG-3'; 7RPL-RV: 5'-TCCACAGCA CTGATGTTTCC-3') were designed to amplify the internal reference gene (Lee et al. 2016). qPCR data were calculated using the $2^{-\Delta \Delta \mathrm{CT}}$ method. The melt-curve analysis was performed to analyze the specificity of the PCR products.

\section{Construction of the pPIC9K-HdhCu/Zn-SOD vector}

The upstream primer F1: GGGGAATTCTCTATCAAA GCAGTTTGTG and the downstream primer R1: ATGCG GCCGCTCAATGGTGATGGTGATGATGCTTGG TGA TGCCGATCA, which are specific to the Pacific abalone $\mathrm{HdhCu} / \mathrm{Zn}$-SOD gene, were designed based on the multiple cloning sites of the pPIC9K vector. The underlined sections are the endonuclease sites for EcoRI and NotI, respectively. A histidine tag was included before the stop codon; the boxed region is the $6 \times$ His-tag. Protein expression and purification followed as previously described (Peng et al. 2012).

The HdhCu/Zn-SOD sequence was obtained from a transcriptome library in our previous study (GenBank accession no. KX302627). The Pacific abalone cDNA sequence was used as a template, and $\mathrm{HdhCu} / \mathrm{Zn}-\mathrm{SOD}$ S1 (5'-GGATTTATTCTCTTTGATAGACAGT-3') and $\mathrm{HdhCu} / \mathrm{Zn}$-SOD A1 (5'-GACACCTCGGCAACCATT AC- $\left.3^{\prime}\right)$ were used as upstream and downstream primers, respectively, to amplify the target gene sequence. Thereafter, the sequence was ligated to pMD18-T to obtain a recombinant-positive plasmid containing the $\mathrm{HdhCu} /$ $\mathrm{Zn}$-SOD target gene. This positive plasmid was used as an amplification template, and $\mathrm{HdhCu} / \mathrm{Zn}-\mathrm{SOD} \mathrm{F} 1$ and $\mathrm{HdhCu} / \mathrm{Zn}$-SOD R1 were used as upstream and downstream primers, respectively, to amplify the target gene sequence using TransStart FastPfu high-fidelity DNA polymerase (TransGen Biotech Co., Ltd.). The recovered Pacific abalone $\mathrm{HdhCu} / \mathrm{Zn}-\mathrm{SOD}$ target gene fragment $(20 \mu \mathrm{g})$ was double digested with the EcoRI and NotI restriction endonucleases (TaKaRa Bio. Inc.). The pPIC9K vector was simultaneously subjected to double digestion with EcoRI and NotI. A DNA Ligation Kit (TaKaRa Bio. Inc.) was used to ligate pPIC9K and the $\mathrm{HdhCu} / \mathrm{Zn}$-SOD gene fragment at $16{ }^{\circ} \mathrm{C}$. The ligation product was transformed into competent $E$. coli $\mathrm{DH} 5 \alpha$ cells, which were then spread on an LB agar plate containing ampicillin and incubated at $37{ }^{\circ} \mathrm{C}$. Positive clones were identified using PCR and submitted to Sangon Biotech (Shanghai) Co., Ltd. for DNA sequencing.

\section{Transformation of $P$. pastoris and PCR analysis of $P$. pastoris transformants}

Bacterial strains containing the correct recombinant expression vector were streaked on a plate, and a single clone was selected for shaking incubation. After the plasmid was obtained, the SacI restriction endonuclease (TaKaRa Bio. Inc.) was used for linearization. The nucleic acid precipitant was used to recover the linearized pPIC9K- $\mathrm{HdhCu} /$ $\mathrm{Zn}$-SOD, which was transformed into competent $P$. pastoris GS115 cells by electroporation. The transformed cells were plated on minimal dextrose (MD) plates and cultured at $28{ }^{\circ} \mathrm{C}$ for 2 days. Single clones were selected for PCR amplification to verify whether the target gene fragment was inserted into the yeast genome using 5'AOX1 (5'-GACTGG TTCCAATTGACAAGC -3') and 3'AOX1 (5'- GCAAAT GGCATTCTGACATCC $-3^{\prime}$ ) as primers. 


\section{Eukaryotic expression of the pPIC9K-HdhCu/Zn-SOD vector and purification}

A single colony on the MD plate was subcultured onto a yeast extract peptone dextrose medium (YPD) plate, which was then inverted for culture at $28^{\circ} \mathrm{C}$. A single colony was grown in $10 \mathrm{~mL}$ of buffered glycerol-complex medium (BMGY, 1\% yeast extract, 2\% tryptone, $1.34 \%$ yeast nitrogen base (YNB), $1 \%$ glycerol, $4 \times 10^{-5} \%$ biotin, and $100 \mathrm{mM}$ potassium phosphate buffer, $\mathrm{pH}$ 6.0) and cultured at 28 ${ }^{\circ} \mathrm{C}$ and $230 \mathrm{rpm}$ until an $\mathrm{OD}_{600}$ of 2.0-6.0 was obtained. The culture was centrifuged at $2000 \mathrm{~g}$ for $5 \mathrm{~min}$, and the supernatant was discarded. An equal volume of buffered methanol-complex medium (BMMY, 1\% yeast extract, $2 \%$ tryptone, $1.34 \% \mathrm{YNB}, 4 \times 10^{-5} \%$ biotin, $0.5 \%$ methanol, and $100 \mathrm{mM}$ potassium phosphate buffer, $\mathrm{pH}$ 6.0) was used to resuspend the cells, and the cells were divided. The $\mathrm{pH}$ was adjusted to $4,5,6,7$, or 8 , and the yeast were incubated at $28{ }^{\circ} \mathrm{C}$ and $230 \mathrm{rpm}$ for $24 \mathrm{~h}$ to induce expression. Different methanol concentrations $(0.5 \%, 1.0 \%, 2.0 \%, 3.0 \%)$ were added. Pre-induction samples of the yeast cultures $(1 \mathrm{~mL})$ were collected at $0 \mathrm{~h}, 6 \mathrm{~h}, 12 \mathrm{~h}, 24 \mathrm{~h}, 48 \mathrm{~h}, 72 \mathrm{~h}$, and $96 \mathrm{~h}$. The samples were centrifuged at $12,000 \mathrm{~g}$ for $10 \mathrm{~min}$ at 4 ${ }^{\circ} \mathrm{C}$, and $900 \mu \mathrm{L}$ of supernatant was collected. Then, 100 $\mu \mathrm{L}$ of trichloroacetic acid was added to the supernatant for protein concentration. Sodium dodecyl sulphate-polyacrylamide gel electrophoresis (SDS-PAGE) electrophoresis was used to analyze the expression level of the target protein. The remaining supernatant of the expression culture was dialyzed three times in dialysis buffer. The solution was centrifuged, and the supernatant was filtered through a $0.45 \mu \mathrm{m}$ filter membrane before purification.

Three to five column volumes of MilliQ water were used to wash the prepacked column (HisTrapTM FF Crude $5 \mathrm{~mL}$ ), after which 3-5 column volumes of equilibration buffer $(20 \mathrm{mM}$ phosphate buffer $+50 \mathrm{mM} \mathrm{NaCl}+10 \mathrm{mM}$ imidazole, $\mathrm{pH}$ 8.5) were used to equilibrate the column. The filtered supernatant was loaded onto the column at $2 \mathrm{~mL} / \mathrm{min}$, and the eluate was collected. Next, 3-5 column volumes of equilibration buffer were used to wash away unbound protein from the column, after which elution buffer (20 $\mathrm{mM}$ phosphate buffer $+50 \mathrm{mM} \mathrm{NaCl}+1 \mathrm{M}$ imidazole, $\mathrm{pH}$ 8.5) was used to elute the protein. The elution peaks of the protein were collected, and small amounts were validated using SDS-PAGE electrophoresis.

\section{Enzyme activity assay}

Various concentrations of $\mathrm{CuSO}_{4}(0,0.2 \%, 0.5 \%$, and $1 \%)$ were added to the induction medium, followed by culture for $24 \mathrm{~h}$. The enzyme activity of the purified $\mathrm{HdhCu} / \mathrm{Zn}$ SOD protein was measured by the SOD assay kit (Nanjing Jiancheng Institute of Biological Engineering, China) according to manufacturer's instructions, based on its ability to inhibit the oxidation of hydroxylamine by the xanthinexanthine oxidase system (Ōyanagui, 1984). We assessed the effect of temperature on SOD enzyme activity. The enzyme samples were incubated for $10 \mathrm{~min}$ at $30{ }^{\circ} \mathrm{C}, 40{ }^{\circ} \mathrm{C}, 50$ ${ }^{\circ} \mathrm{C}, 60{ }^{\circ} \mathrm{C}, 70{ }^{\circ} \mathrm{C}$ and $80{ }^{\circ} \mathrm{C}$ in $1 \times$ phosphate buffer saline (PBS), and then immediately transferred and kept on ice for the determination of residual enzymatic activity (Xu et al, 2010).

\section{Measurement of antioxidant activity of recombinant protein}

The SOD activity scavenging superoxide anions and hydroxyl free radicals was estimated using commercial kits (Nanjing Jiancheng Bio-Engineering Institute Co., Ltd.) following the manufacturer's instructions. The 3-(4,5-dimethylthiazol-2-yl)-5-(3-carboxymethoxyphenyl)-2-(4-sulfonyl)$2 \mathrm{H}$-tetrazolium/phenazine methosulfate (MTS/PMS) assay was used to measure the effects of $\mathrm{HdhCu} / \mathrm{Zn}-\mathrm{SOD}$ on $\mathrm{L} 929$ (a mouse fibroblast cell line) cell viability following a published study. L929 cells were cultured at $37{ }^{\circ} \mathrm{C}$ under $5 \%$ $\mathrm{CO}_{2}$ and then treated with different concentrations of the recombinant $\mathrm{HdhCu} / \mathrm{Zn}-\mathrm{SOD}$ protein $(0,12.5,25,50$, and $100 \mu \mathrm{g} / \mathrm{mL}$ ) for $24 \mathrm{~h}$. The MTS/PTS cell proliferation working solution was added, and the cells were incubated in the dark for $0.75-2 \mathrm{~h}$. The absorbance at $490 \mathrm{~nm}$ was measured using a microplate reader.

In the cell oxidative damage experiment, $150 \mu \mathrm{M} \mathrm{H}_{2} \mathrm{O}_{2}$ was used to treat L929 cells. Different concentrations of recombinant $\mathrm{HdhCu} / \mathrm{Zn}$-SOD protein $(0,12.5,25,50$, and $100 \mu \mathrm{g} / \mathrm{mL}$ ) were added, and nonhydrogen peroxide-treated cells were used as a blank control. The cells were incubated at $37{ }^{\circ} \mathrm{C}$ under $5 \% \mathrm{CO}_{2}$ for $3 \mathrm{~h}$ before the MTS/PMS cell proliferation working solution was added. The aforementioned measurement method was used.

\section{Hemolysis experiment}

The horse erythrocyte hemolysis experiment was carried out as previously described (Wu et al. 2019). A 4\% horse erythrocyte suspension was prepared in PBS solution. Different concentrations of $\mathrm{HdhCu} / \mathrm{Zn}-\mathrm{SOD}(0,7.5$, $15,30,60,120,240,480$, and $960 \mu \mathrm{g} / \mathrm{mL}$ ) were treated with an equal volume of horse erythrocytes at $37{ }^{\circ} \mathrm{C}$ for $2 \mathrm{~h}$. PBS $(0 \mu \mathrm{g} / \mathrm{mL})$ and Triton X-100 were used as negative and positive controls, respectively. After centrifugation at $900 \times g$ for $5 \mathrm{~min}, 200 \mu \mathrm{L}$ of the supernatant of each concentration was transferred to a 96-well plate. The OD values were measured at $500 \mathrm{~nm}$. Each concentration was prepared in quadruplicate. The percentage of hemolysis was calculated using the following equation: $\%$ hemolysis $=(\mathrm{A}-\mathrm{A} 0) /(\mathrm{AX}-\mathrm{A} 0) \times 100$, where ' $\mathrm{A}$ ' is $\mathrm{OD}$ 
at $500 \mathrm{~nm}$ with $\mathrm{HdhCu} / \mathrm{Zn}$-SOD solution, 'A0' is OD at $500 \mathrm{~nm}$ in PBS, and 'AX' is OD at $500 \mathrm{~nm}$ with $0.1 \%$ Triton X 100.

\section{Statistical analysis}

One-way ANOVA and the independent-samples t-test were performed to compare the differences in relevant data using SPSS software (version 24.0). The results were considered as significant when $\mathrm{p}<0.05$. The asterisks indicate $* \mathrm{p}<0.05, * * \mathrm{p}<0.01$, and $* * * \mathrm{p}<0.001$. All data and graphs are expressed as the mean \pm standard error.

\section{Results}

\section{Tissue distribution of HdhCu/Zn-SOD mRNA}

To investigate the transcript distribution of $\mathrm{HdhCu} / \mathrm{Zn}$ SOD among various tissues, qPCR was performed. The $\mathrm{HdhCu} / \mathrm{Zn}$-SOD mRNA exhibited a broad tissue distribution, being found in the hemocytes, gills, mantle, digestive glands, and shell muscle, etc. The $\mathrm{HdhCu} / \mathrm{Zn}-\mathrm{SOD}$ mRNA showed the highest expression level in the digestive glands, hemocytes, and gills $(\mathrm{p}<0.05$, compared to

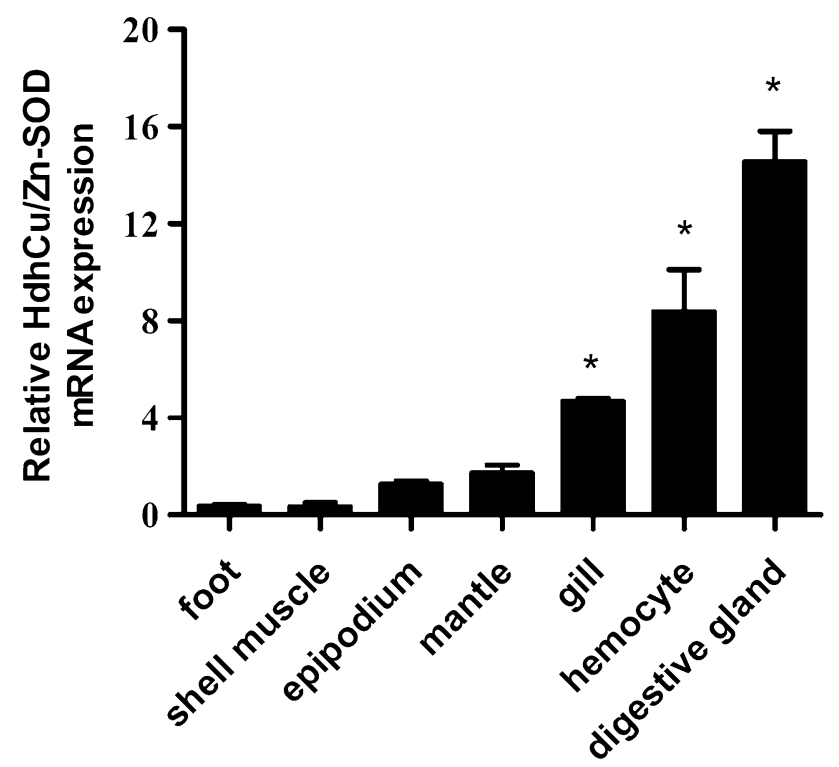

Fig. 1 Expression of $\mathrm{HdhCu} / \mathrm{Zn}-\mathrm{SOD}$ in various Pacific abalone tissues and organs. $\beta$-actin was used as a housekeeping gene. The bars show the standard errors of mean values. These results were analyzed using an independent-samples $t$-test and asterisks represent significant differences compared to the shell muscle $(* p<0.05)$ the shell muscle). Poor expression was observed in the shell muscle and foot (Fig. 1).

\section{Expression characteristics of HdhCu/Zn-SOD in Pacific abalone hemocytes after LPS stimulation}

qPCR was performed to estimate the expression level of the $\mathrm{HdhCu} / \mathrm{Zn}$-SOD gene in response to LPS challenge. The $\mathrm{HdhCu} / \mathrm{Zn}-\mathrm{SOD}$ gene transcript was overexpressed in the digestive gland at $48 \mathrm{~h}$ (3.86-fold vs the control, $\mathrm{p}=0.003)$ and maintained high expression until $96 \mathrm{~h}$ postLPS injection (2.17-fold vs the control, $p=0.033$ ) (Fig. 2). The mRNA expression pattern was different in hemocytes after LPS challenge, with upregulation observed at $96 \mathrm{~h}$ (1.87-fold vs the control, $\mathrm{p}=0.003$ ). The transcript level of $\mathrm{HdhCu} / \mathrm{Zn}$-SOD in the gills was upregulated at $4 \mathrm{~h}$ (2.13-fold vs the control, $\mathrm{p}=0.026)$ and downregulated at other time points. These results confirm a tissue- and time-dependent expression pattern of $\mathrm{HdhCu} / \mathrm{Zn}-\mathrm{SOD}$ in abalones in response to LPS challenge.

\section{Construction and identification of the recombinant expression vector}

The expression vector used in the experiment contains an AOX1 promoter and a yeast signal peptide $\alpha$-factor that induces the secretion of the target gene. The six histidine residues that are fused at the $\mathrm{C}$-terminus enable the target protein to be purified using $6 \times$ His-Tag affinity chromatography. After the PCR-amplified HdhCu/Zn-SOD target gene was digested with EcoRI and NotI, it was ligated to the digested pPIC9K vector before transformation into E. coli DH5 $\alpha$. Positive clones were selected for sequencing by Sangon Biotech (Shanghai) Co., Ltd. The results showed that the ligation was correct, and the open reading frame (ORF) of the nucleotides was encoded continuously, which confirmed the amino acid sequence to be expressed. Figure 3a shows the construction of the pPIC9K-HdhCu/ $\mathrm{Zn}$-SOD expression vector.

The recombinant pMD18-T plasmid positive for $\mathrm{HdhCu} / \mathrm{Zn}$-SOD was used as a PCR template. The mature $\mathrm{HdhCu} / \mathrm{Zn}$-SOD peptide sequence (GenBank accession no. KX302627) was amplified by PCR, and a $462 \mathrm{bp}$ PCR product encoding 154 amino acids was cloned into the pPIC9K expression vector (Fig. 3b). The amplified $\mathrm{HdhCu} / \mathrm{Zn}-\mathrm{SOD}$ target fragment was double digested with the restriction endonucleases EcoRI and NotI to obtain a gene fragment that could be ligated with pPIC9k containing the same sticky ends. The digested pPIC9K plasmid was loaded into a $0.8 \%(\mathrm{w} / \mathrm{v})$ agarose gel and subjected to electrophoresis in Tris-acetate-EDTA buffer to measure the cleavage efficiency (Fig. 3c). 


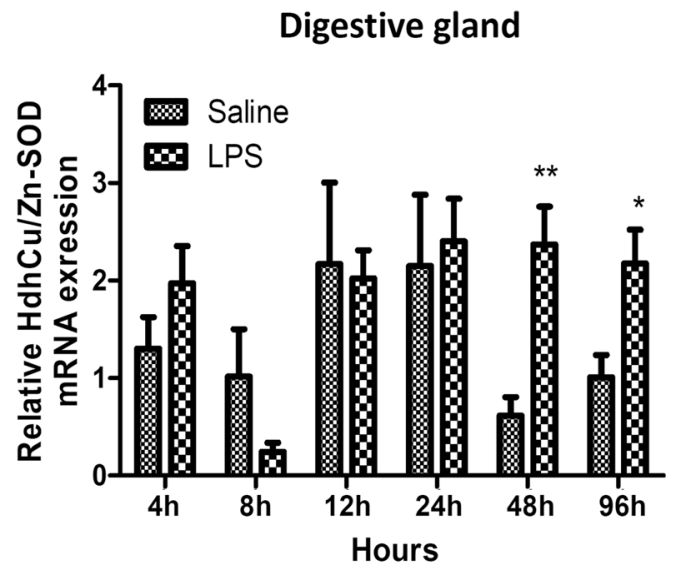

Gill

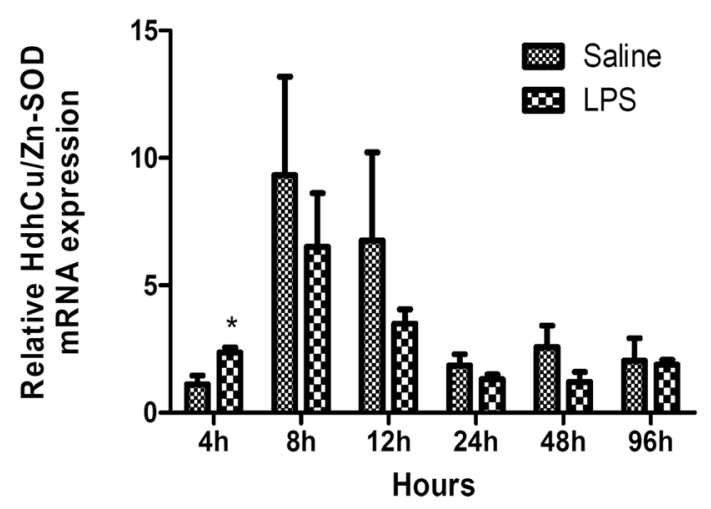

Fig. 2 Time course of the mRNA expression of $\mathrm{HdhCu} / \mathrm{Zn}-\mathrm{SOD}$ in the hemocytes, gills, digestive glands, and gonads after LPS challenge. RPL7 was used as a housekeeping gene. The bars show the

\section{Optimization of induction conditions for $\mathrm{HdhCu}$ / Zn-SOD expression}

After the pPIC9K-HdhCu/Zn-SOD recombinant plasmid was transformed into P. pastoris GS115 cells, single clones were cultured in $10 \mathrm{~mL}$ of BMGY culture medium for $16 \mathrm{~h}$ until the logarithmic growth phase was reached, and the cells were collected by centrifugation. Next, we compared different expression durations $(0 \mathrm{~h}, 6 \mathrm{~h}, 12 \mathrm{~h}, 24 \mathrm{~h}, 48 \mathrm{~h}, 72 \mathrm{~h}$, or $96 \mathrm{~h}$ ), $\mathrm{pH}$ levels of the expression medium (BMMY culture medium with $\mathrm{pH} 4,5,6,7$, or 8), and methanol concentrations at induction $(0.5 \%, 1.0 \%, 2.0 \%$, or $3.0 \%)$. The protein was expressed $12 \mathrm{~h}$ after methanol induction with a molecular weight of approximately $17 \mathrm{kDa}$ and $21 \mathrm{kDa}$ (Fig. 4a). In the range of methanol concentrations, the expression of the $\mathrm{HdhCu} / \mathrm{Zn}-\mathrm{SOD}$ protein was highest at $0.5 \%$ methanol (Supplementary Fig.S1a). The induction of $\mathrm{HdhCu} / \mathrm{Zn}-\mathrm{SOD}$ expression at different initial $\mathrm{pH}$ showed that the highest protein expression occurred at the initial $\mathrm{pH}$ of 6.0 (Supplementary Fig.S1b).

\section{Hemocyte}

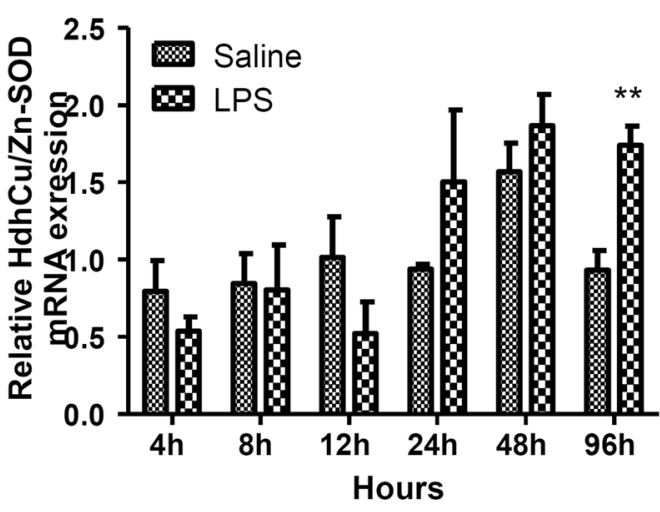

Gonad

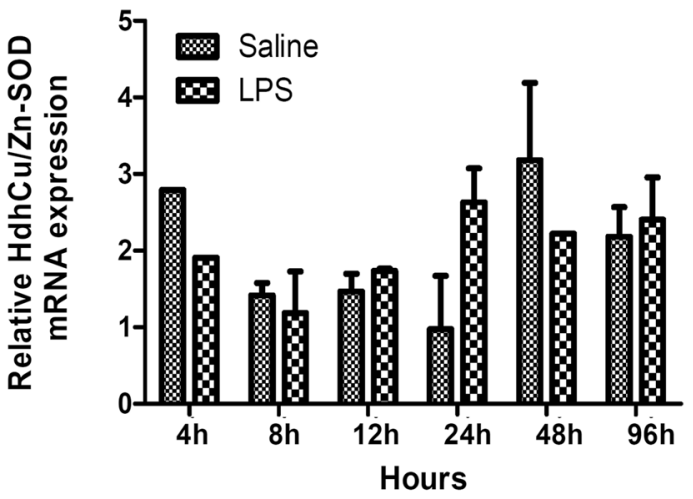

standard errors of mean values. These results were analyzed using an independent-samples $t$-test and asterisks represent significant difference compared with the saline group $(* \mathrm{p}<0.05 ; * * \mathrm{p}<0.01)$

\section{Purification of the recombinant HdhCu/Zn-SOD protein}

Immobilized metal-chelate affinity chromatography using nickel ions was employed for purification. $\mathrm{HdhCu} / \mathrm{Zn}-\mathrm{SOD}$ can specifically bind nickel ions in the affinity chromatography column. Based on the ultraviolet absorption curve detected at $280 \mathrm{~nm}$, the wash components were impure proteins, while the elution component was the chelated target protein, $\mathrm{HdhCu} / \mathrm{Zn}-\mathrm{SOD}$. The purified protein was subjected to SDS-PAGE electrophoresis (Fig. 4b), and the two target bands (approximately $17 \mathrm{kDa}$ and $21 \mathrm{kDa}$ ) were excised for matrix-assisted laser desorption/ionization time-of-flight/time-of-flight mass spectrometry (MALDITOF/TOF-MS) protein mass spectrometry analysis (Supplementary Fig. S2). Comparison with the protein mass spectrometry database showed that the polypeptide fragments matched the amino acid sequence of $\mathrm{HdhCu} / \mathrm{Zn}$ SOD, demonstrating that the recovered bands were the target protein $\mathrm{HdhCu} / \mathrm{Zn}-\mathrm{SOD}$. 
Fig. 3 Construction of the recombinant expression vector. a Structural map of the PIC9K$\mathrm{HdhCu} / \mathrm{Zn}-\mathrm{SOD}$ recombinant plasmid vector. b Electropherogram of the PCR product of the $\mathrm{HdhCu} / \mathrm{Zn}$-SOD expression fragment. Lane M: DL2000 Plus DNA Marker; lane 1: PCR product of $\mathrm{HdhCu} / \mathrm{Zn}-\mathrm{SOD}$. c pPIC9K plasmid map after double enzymatic digestion. Lane M1: DL2000 Plus DNA Marker; lane 1: Before enzymatic cleavage of the vector; lane 2: After enzymatic cleavage of the vector; lane M2: $\lambda$ HindIII DNA Marker a

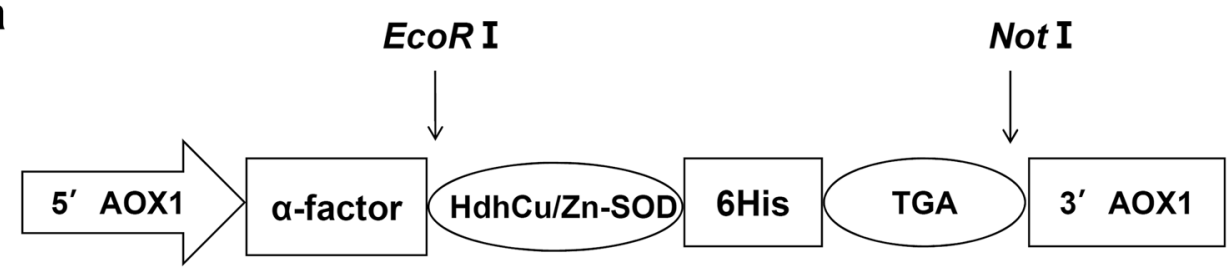

b
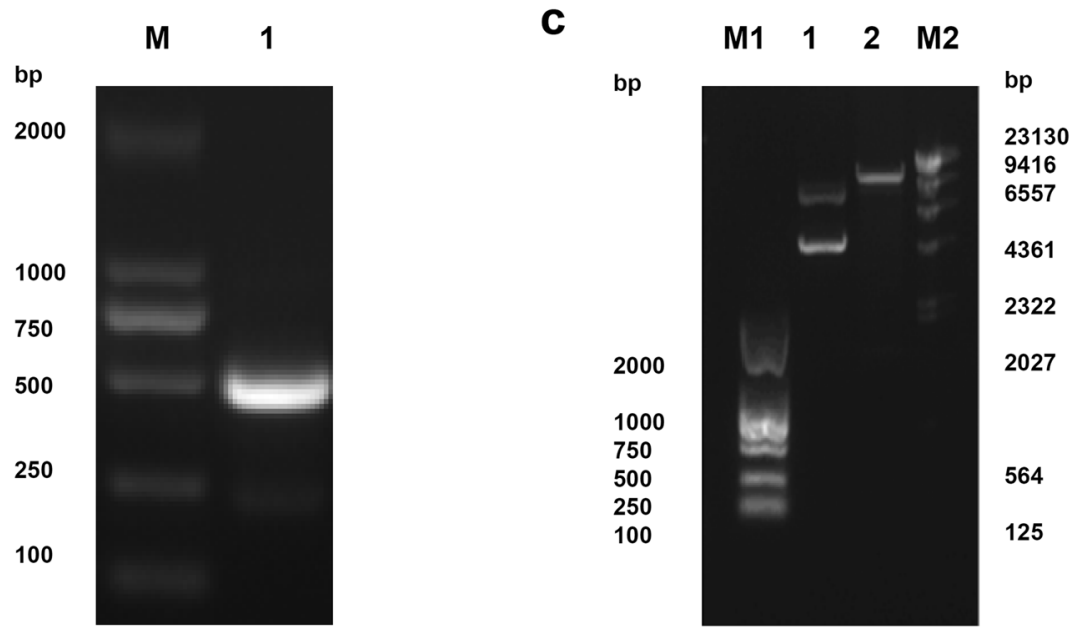

\section{Assessment of $\mathrm{HdhCu} / \mathrm{Zn}-\mathrm{SOD}$ enzyme activity}

The $\mathrm{HdhCu} / \mathrm{Zn}$-SOD activities in the presence of $\mathrm{Cu}^{2+}$ were measured. The results showed that the enzymatic activity of $\mathrm{HdhCu} / \mathrm{Zn}$-SOD consistently increased with an increase in $\mathrm{Cu}^{2+}$ concentrations and showed statistical significance $(\mathrm{p}<0.001)$ compared with the $0 \% \mathrm{CuSO}_{4}$. $\mathrm{HdhCu} / \mathrm{Zn}$ SOD activity was the greatest at a $1 \% \mathrm{Cu}^{2+}$ concentration (Fig. 5a).

The effect of temperature on SOD enzyme activity was measured. The maximum SOD activity measured was considered to be $100 \%$. The SOD activity was above $80 \%$ at $30-65^{\circ} \mathrm{C}$. As the temperature gradually increased, the SOD activity of $\mathrm{HdhCu} / \mathrm{Zn}-\mathrm{SOD}$ decreased, reaching $62 \%$ at 80 ${ }^{\circ} \mathrm{C}$. These results show that the $\mathrm{HdhCu} / \mathrm{Zn}$-SOD protein presents good thermal stability (Fig. 5b).

\section{The ability of recombinant $\mathrm{HdhCu} / \mathrm{Zn}$-SOD in scavenging superoxide anions and hydroxyl free radicals}

As the $\mathrm{HdhCu} / \mathrm{Zn}-\mathrm{SOD}$ protein concentration increased, the superoxide anion scavenging activity of the $\mathrm{HdhCu} / \mathrm{Zn}$ SOD protein also increased. Dose-dependent scavenging is visible at up to $0.1 \mathrm{mg} / \mathrm{mL}$, after which the scavenging becomes saturated (Fig. 6a). When the $\mathrm{HdhCu} / \mathrm{Zn}$-SOD protein concentration was $0.001 \mathrm{mg} / \mathrm{mL}$, the superoxide anion scavenging activity was $50 \%$. In comparison, the glutathione (GSH) concentration associated with the 50\% superoxide anion scavenging activity was $30.35 \mathrm{mg} / \mathrm{mL}$ (Fig. 6b). The results showed that recombinant $\mathrm{HdhCu} / \mathrm{Zn}-\mathrm{SOD}$ presented a good superoxide anion scavenging ability.

The 50\% hydroxyl free radical scavenging activity for the $\mathrm{HdhCu} / \mathrm{Zn}$-SOD protein was $0.016 \mathrm{mg} / \mathrm{mL}$ (Fig. 6c). When GSH was used as a positive control, the GSH concentration associated with a 50\% hydroxyl free radical scavenging activity was $7.88 \mathrm{mg} / \mathrm{mL}$ (Fig. 6d). The results showed that the recombinant $\mathrm{HdhCu} / \mathrm{Zn}$-SOD protein possessed a strong hydroxyl free radical scavenging ability.

\section{Protective effects of recombinant $\mathrm{HdhCu} / \mathrm{Zn}$-SOD against $\mathrm{H}_{2} \mathrm{O}_{2}$-induced cellular damage}

To determine whether the $\mathrm{HdhCu} / \mathrm{Zn}$-SOD protein reduces cell viability, different concentrations of purified $\mathrm{HdhCu} / \mathrm{Zn}$-SOD protein were added to L929 cells, followed by $24 \mathrm{~h}$ of culture. The MTS/PMS method was used to measure the effects of $\mathrm{HdhCu} / \mathrm{Zn}$-SOD on L929 cell viability (Fig. 7a). The results showed that $\mathrm{HdhCu} /$ $\mathrm{Zn}$-SOD protein did not affect the viability of L929 cells at concentrations of $12.5-100 \mu \mathrm{g} / \mathrm{mL}$ relative to the normal cells $(0 \mu \mathrm{g} / \mathrm{mL}, \mathrm{p}>0.05)$. L929 cells were treated with various concentrations of $\mathrm{H}_{2} \mathrm{O}_{2}(0-250 \mu \mathrm{M})$ for $3 \mathrm{~h}$ to determine the $\mathrm{H}_{2} \mathrm{O}_{2}$ concentration at which oxidative damage was induced. The cell viability was reduced in a concentration-dependent manner upon exposure to $\mathrm{H}_{2} \mathrm{O}_{2}$ (Fig. 7b). Normal cells (nonhydrogen peroxide (-) with no protein $(0 \mu \mathrm{g} / \mathrm{mL})$-treated cells $)$ were used as blank 


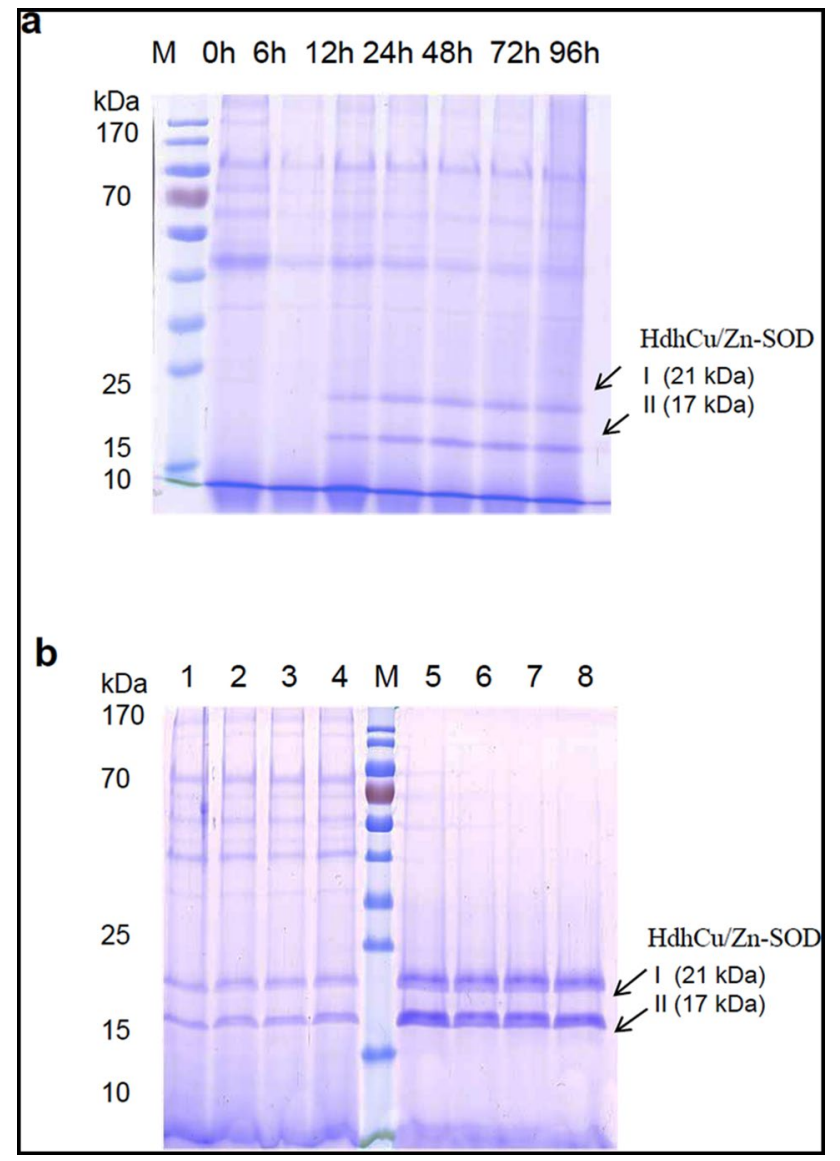

Fig. 4 Recombinant expression and purification of the $\mathrm{HdhCu} / \mathrm{Zn}$ SOD protein. a The recombinant $\mathrm{HdhCu} / \mathrm{Zn}-\mathrm{SOD}$ expressed after different induction times $(0 \mathrm{~h}, 6 \mathrm{~h}, 12 \mathrm{~h}, 24 \mathrm{~h}, 48 \mathrm{~h}, 72 \mathrm{~h}$, and $96 \mathrm{~h})$. b SDS-PAGE analysis of the purified $\mathrm{HdhCu} / \mathrm{Zn}-\mathrm{SOD}$ protein. Lane M: Protein marker 26,616 (Thermo Scientific); lane 1-4: Unpurified $\mathrm{HdhCu} / \mathrm{Zn}-\mathrm{SOD}$ protein.; lane 5-8: Purified $\mathrm{HdhCu} / \mathrm{Zn}-\mathrm{SOD}$ protein. Arrows show band I (21 kDa) and band II (17 kDa) of purified $\mathrm{HdhCu} / \mathrm{Zn}-\mathrm{SOD}$ protein

controls and the cell viability was considered as $100 \%$. Treatment of L929 cells only with $\mathrm{H}_{2} \mathrm{O}_{2}(150 \mu \mathrm{M})$ significantly decreased cell viability $(\mathrm{p}=0.008)$. Additionally, $150 \mu \mathrm{M} \mathrm{H}_{2} \mathrm{O}_{2}$ and $\mathrm{HdhCu} / \mathrm{Zn}$-SOD protein at varying concentrations were coincubated with L929 cells. As the $\mathrm{HdhCu} / \mathrm{Zn}$-SOD protein concentration (from 0 to $50 \mu \mathrm{g} / \mathrm{mL}$ ) increased, the viability of the L929 cells continuously increased (Fig. 7c). The viability of L929 cells in the 25,50 , and $100 \mu \mathrm{g} / \mathrm{mL} \mathrm{HdhCu} / \mathrm{Zn}-\mathrm{SOD}$ protein groups was higher than that in the $0 \mu \mathrm{g} / \mathrm{mL} \mathrm{HdhCu} /$ $\mathrm{Zn}$-SOD protein group. The $50 \mu \mathrm{g} / \mathrm{mL} \mathrm{HdhCu} / \mathrm{Zn}$-SOD protein group showed 1.30 -fold higher viability than the $0 \mu \mathrm{g} / \mathrm{mL}$ group $(\mathrm{p}=0.005)$. Thus, $\mathrm{HdhCu} / \mathrm{Zn}-\mathrm{SOD}$ protein can protect $\mathrm{L} 929$ cells against peroxidation damage caused by $\mathrm{H}_{2} \mathrm{O}_{2}$.

\section{Hemolysis assessment of the recombinant $\mathrm{HdhCu} /$ Zn-SOD protein}

To evaluate the cytotoxicity of recombinant $\mathrm{HdhCu} / \mathrm{Zn}$ SOD protein, healthy mammalian red blood cells were treated with this protein. $\mathrm{HdhCu} / \mathrm{Zn}-\mathrm{SOD}$ was coincubated with horse erythrocytes for $2 \mathrm{~h}$, followed by centrifugation. The supernatant was collected for $\mathrm{OD}_{500}$ measurement. The results showed that as the $\mathrm{HdhCu} / \mathrm{Zn}$-SOD protein concentration increased, no hemolysis occurred at protein concentration lower than $960 \mu \mathrm{g} / \mathrm{mL}$ (Fig. 8). Slight hemolysis was observed in horse erythrocytes at a concentration of $960 \mu \mathrm{g} /$ $\mathrm{mL}$, which is nearly 10 times the maximum working concentration $(100 \mu \mathrm{g} / \mathrm{mL})$.

\section{Discussion}

The present study demonstrates that $\mathrm{HdhCu} / \mathrm{Zn}$-SOD is a ubiquitous enzyme, and the gene encoding this protein exhibits tissue-specific expression. We also found that $\mathrm{HdhCu} / \mathrm{Zn}$-SOD is up-regulated following LPS stimulation leading to oxidative stress. Furthermore, $\mathrm{HdhCu} / \mathrm{Zn}-\mathrm{SOD}$ activity is markedly increased in the presence of $\mathrm{Cu}^{2+}$ salts. In addition to this, $\mathrm{HdhCu} / \mathrm{Zn}$-SOD exhibits a good heat stability profile and is shown to have scavenging action against superoxide anion and hydroxyl radical in vitro.

Expression of the gene encoding $\mathrm{HdhCu} / \mathrm{Zn}-\mathrm{SOD}$ was detected by qPCR in all tissues of $H$. discus hannai, indicating that $\mathrm{HdhCu} / \mathrm{Zn}-\mathrm{SOD}$ may be a ubiquitous enzyme. We also found that $\mathrm{HdhCu} / \mathrm{Zn}$-SOD expression was the highest in the digestive gland, followed by hemocytes and gills, and was lower in muscle tissue. The digestive system of abalone consists of the digestive tract, and digestive gland (hepatopancreas) (Wigham 1976). As the main metabolic organ, the digestive gland is considered to be the major site for accumulation of toxic metals and bacteria, playing an important role in the regulation of oxidative stress and clearance of oxidative stress products. Hemocytes have been known as the important immune factor, playing an important role in cellular immunity in invertebrates, with the gill acting as a barrier to various exogenous stimuli. The digestive glands, gills, and blood are important immune organs; thus, the high expression of $\mathrm{HdhCu} / \mathrm{Zn}-\mathrm{SOD}$ in these tissues suggests that it may participate in the immune response against infection in mollusks. These results are somewhat similar to those reported by De Zoysa et al. (2009), who showed, using semi-quantitative RT-PCR, that SOD of $H$. discus discus was highly expressed in the digestive tract and gill. Similarly, for Mg-MnSOD and Mg-Cu/Zn-SOD of Mytilus galloprovincialis and $\mathrm{Mm}-\mathrm{icCu} / \mathrm{Zn}-\mathrm{SOD}$ of Meretrix meretrix, transcripts were primarily detected in the hepatopancreas (Gao et al. 2012; Wang et al. 2013). The differences in 
a

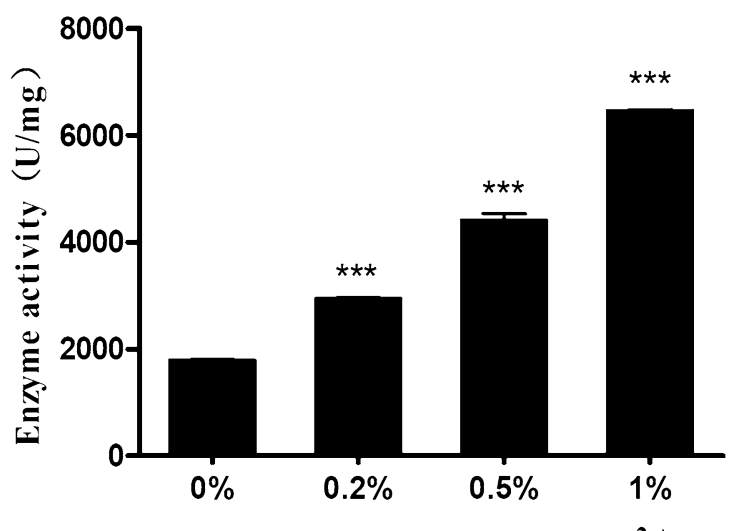

Different concentration of $\mathrm{Cu}^{2+}$ b

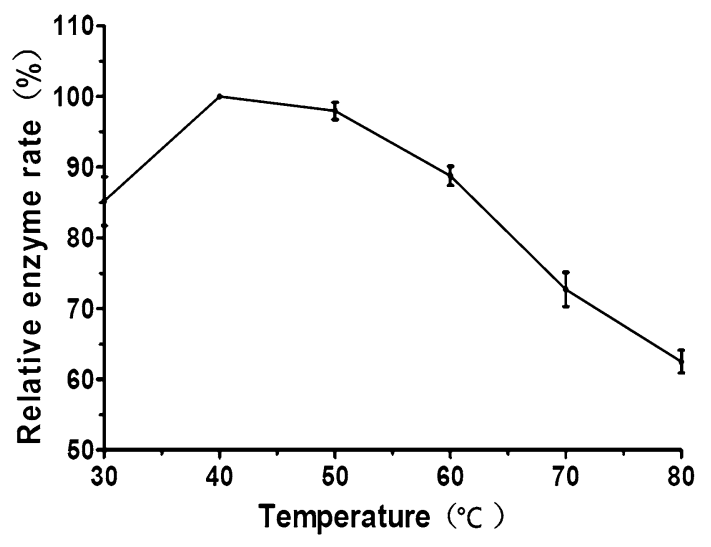

the thermal stability of the enzyme. The recombinant expression product, $\mathrm{HdhCu} / \mathrm{Zn}-\mathrm{SOD}$, was incubated at $30-80{ }^{\circ} \mathrm{C}$ for $10 \mathrm{~min}$. These results were analyzed using an independent-samples $t$-test and asterisks represent significant differences compared to the $0 \% \mathrm{Cu}^{2+}$ concentration $(* \mathrm{p}<0.05, * * \mathrm{p}<0.01, * * * \mathrm{p}<0.001)$ a

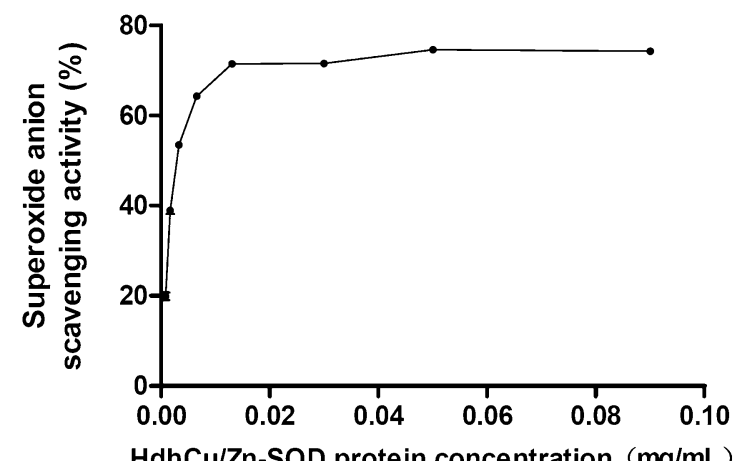

HdhCu/Zn-SOD protein concentration $(\mathrm{mg} / \mathrm{mL})$

C

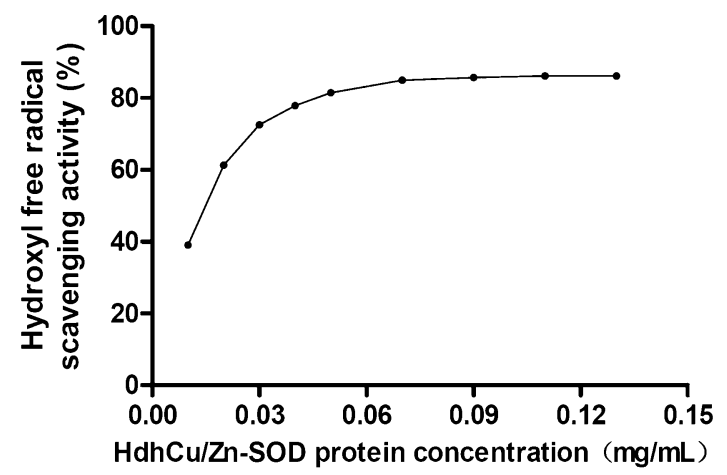

Fig. 6 Comparison of quantitative ability of recombinant $\mathrm{HdhCu} / \mathrm{Zn}$ SOD and GSH to scavenge superoxide anions and hydroxyl free radicals. Superoxide anion scavenging ability of the recombinant $\mathrm{HdhCu} /$ b

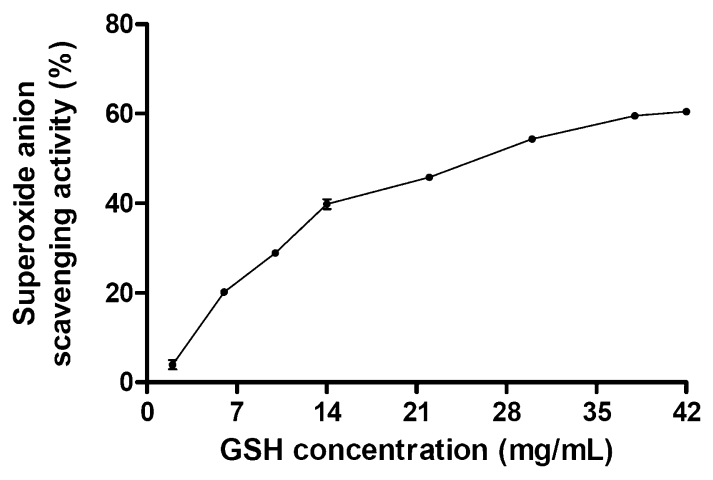

d

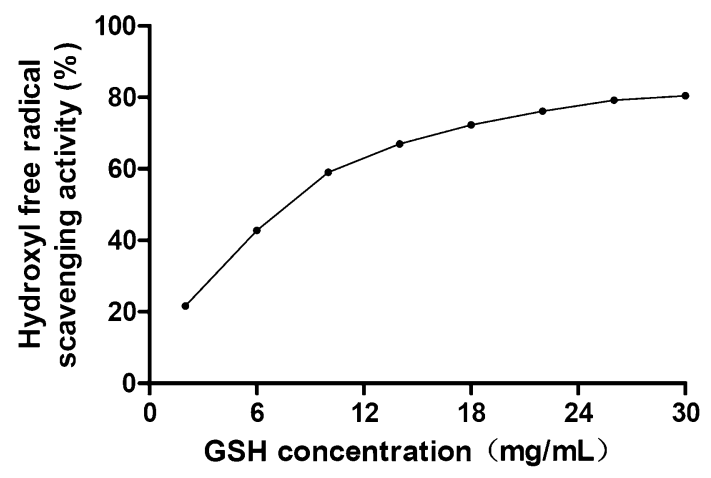

Zn-SOD expression product a and GSH b. Hydroxyl free radical scavenging ability of the recombinant $\mathrm{HdhCu} / \mathrm{Zn}-\mathrm{SOD}$ expression product $\mathbf{c}$ and GSH d 
a

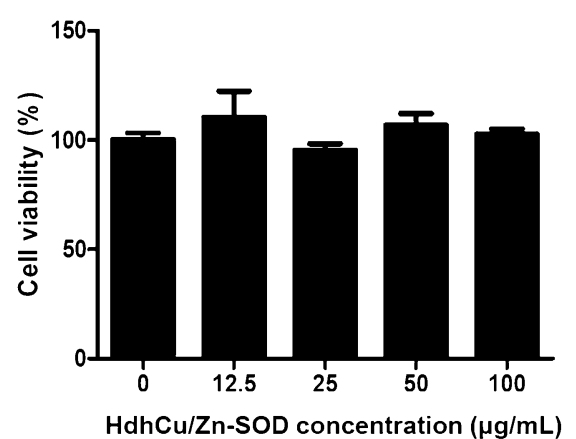

b

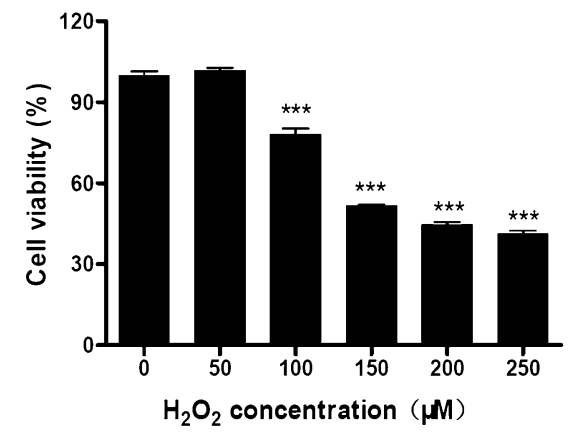

c

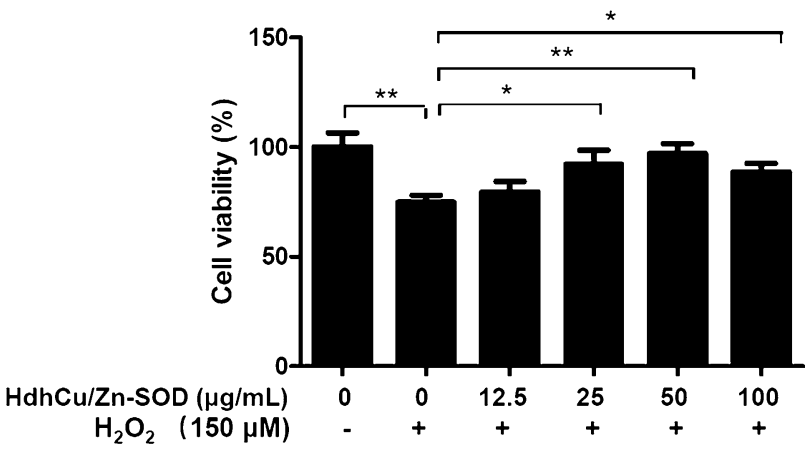

Fig. 7 Effects of recombinant $\mathrm{HdhCu} / \mathrm{Zn}$-SOD on $\mathrm{H}_{2} \mathrm{O}_{2}$-induced cellular damage. a Treatment of $\mathrm{L} 929$ cells with recombinant $\mathrm{HdhCu} /$ Zn-SOD $(0-100 \mu \mathrm{g} / \mathrm{mL})$ showed no significant cell damage. b Treatment of L929 cells with $\mathrm{H}_{2} \mathrm{O}_{2}(0-250 \mu \mathrm{M})$. c Treatment of L929 cells with $\mathrm{H}_{2} \mathrm{O}_{2}(150 \mu \mathrm{M})$ dramatically decreased cell viability, whereas different concentrations of recombinant $\mathrm{HdhCu} / \mathrm{Zn}-\mathrm{SOD}$ $(12.5-100 \mu \mathrm{g} / \mathrm{mL})$ showed protective effects against $\mathrm{H}_{2} \mathrm{O}_{2}$-induced cellular damage. Cell viability was measured by the MTS/PMS assay. The results were analyzed using an independent-samples $t$-test and asterisks represent significant differences compared to the control $(* \mathrm{p}<0.05, * * \mathrm{p}<0.01, * * * \mathrm{p}<0.001)$

tissue distribution profiles of $\mathrm{Cu} / \mathrm{ZnSOD}$ expression may be attributed to the balance of various processes that act on the production of ROS in different environments.

LPS, a major component of gram-negative bacteria, induces proinflammatory transduction pathways, producing a strong immune stimulation response. To investigate the immunological function of $\mathrm{HdhCu} / \mathrm{ZnSOD}$ in the abalone, we studied the transcriptional level of $\mathrm{HdhCu} / \mathrm{Zn}-\mathrm{SOD}$ after LPS stimulation. The results showed that $\mathrm{HdhCu} / \mathrm{Zn}-\mathrm{SOD}$

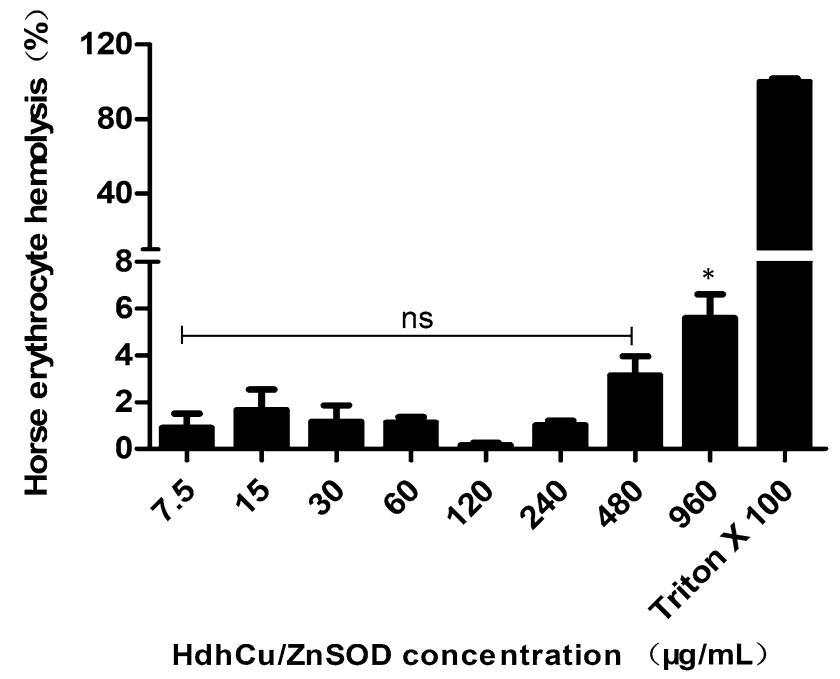

Fig. 8 Hemolytic effects of the recombinant $\mathrm{HdhCu} / \mathrm{Zn}$-SOD expression product on horse erythrocytes

was up-regulated in the digestive gland, hemocytes, and gills, which confirmed the results of previous studies (Anju et al. 2013; Bao et al. 2009b Nikptiya et al. 2008). The phagocytic activity of an abalone infected with bacteria and foreign bodies produces a significant amount of ROS, which needs to be eliminated and this leads to additional transcription and translation of SOD (Nikptiya et al. 2008). Differences in SOD response to LPS among various tissues may be due to the diversity of isoenzymes.

In the present study, a recombinant $\mathrm{HdhCu} / \mathrm{Zn}-\mathrm{SOD}$ protein from $H$. discus hannai was successfully obtained in vitro by optimizing the expression conditions using a $P$. pastoris expression vector. After purification of the protein via immobilized metal affinity chromatography, two bands (approximately 17 and $21 \mathrm{kDa}$ ) were detected by SDS-PAGE and further confirmed by mass spectrometry. A similar observation has been documented in Sánchez-Venegas's study, who found the Deschampsia antarctica recombinant SOD expressed by P. pastoris were showed two bands of 25 and $20 \mathrm{kDa}$. It was verified that SOD was secreted as a glycosylated protein by deglycosylation assays (SánchezVenegas et al, 2009). Given our results, the $17 \mathrm{kD}$ protein corresponds to the estimated molecular weight for $\mathrm{HdhCu} /$ $\mathrm{Zn}$-SOD and the 6xHis-tag. We speculate that the $21 \mathrm{kD}$ band could be a glycoprotein of $\mathrm{HdhCu} / \mathrm{Zn}$-SOD.

Several research groups have employed prokaryotic expression systems (e.g. E. coli) to express recombinant SOD to determine its activity levels and investigate the role of SOD in marine mollusks. De Zosya et al. (2009) described overexpression of a recombinant $\mathrm{Cu} / \mathrm{Zn}$-SOD fusion protein in $E$. coli K12(TB1) cells, reporting an activity level of 2461 $\mathrm{U} / \mathrm{mg}$. In this study, we used a P. pastoris GS115 eukaryotic expression system for in vitro recombinant expression of 
$\mathrm{HdhCu} / \mathrm{Zn}$-SOD from the Pacific abalone. The enzymatic activity of purified $\mathrm{HdhCu} / \mathrm{Zn}$-SOD was greatly increased in the presence of $\mathrm{Cu}^{2+}$, reaching a maximum level of 6,771 $\mathrm{U} / \mathrm{mg}$ in the presence of $1.0 \% \mathrm{Cu}^{2+}$. These findings were consistent with those of a previous study by Xu et al. (2010), who reported that the expression level and activity of $\mathrm{Cu} /$ Zn-SOD from Cristaria plicata were increased by the supplementation of $\mathrm{Cu}^{2+}\left(\right.$ or $\mathrm{Zn}^{2+}$ ) salts. These results showed that copper ions play an important role in improving SOD activity. Similarly, in $H$. diversicolor, the maximum activity of recombinant SOD was $801.8 \mathrm{U} / \mathrm{mg}$ protein in the presence of $1 \mu \mathrm{M} \mathrm{Cu}^{2+}$ and $\mathrm{Zn}^{2+}$ ( $\mathrm{Li}$ et al. 2010). The activity of our recombinant enzyme was higher than that reported previously, possibly because of differences in recombinant expression vectors. P. pastoris is a good heterologous expression host that can more effectively modify proteins after translation compared to prokaryotic expression vectors (Ahmad et al. 2014; Macauley-Patrick et al. 2005).

We assessed the effect of temperature on SOD enzyme activity. $\mathrm{HdhCu} / \mathrm{Zn}$-SOD exhibited a good heat stability profile, with $80 \%$ of the optimal SOD activity maintained over a temperature range of $30-65{ }^{\circ} \mathrm{C}$. The thermal stability of $\mathrm{HdhCu} / \mathrm{Zn}$-SOD was similar to that of other recombinant SOD enzymes, such as $\mathrm{rCp}$-icCuZnSOD, a recombinant protein from a freshwater mussel, and rAi-icCuZnSOD, a bay scallop protein, which retained $>80 \%$ of the optimal activity below $60{ }^{\circ} \mathrm{C}$ (Bao et al. 2009b; Xu et al. 2010). As previously reported, our results confirm that SOD is a thermally stable enzyme.

Superoxide anions and hydroxyl radical, which can attack biological macromolecules and cause irreversible cell damage, are considered to be the main causes of oxidative damage (Zeng et al. 2018). As the first-line enzymatic defense against superoxide, SOD scavenges free radical species produced from endogenous and exogenous substances. To evaluate the antioxidant capacity of recombinant protein in vitro, we measured the ability of a recombinant $\mathrm{HdhCu} / \mathrm{Zn}-\mathrm{SOD}$ protein to scavenge superoxide anions and hydroxyl free radicals. By comparison with GSH (which is typically used as a scavenger positive control, Cai et al. 2015), we found that the purified $\mathrm{HdhCu} / \mathrm{Zn}$-SOD possessed a strong ability to scavenge superoxide anions and hydroxyl free radicals.

In this study, the cytotoxicity of the recombinant protein was evaluated, and it was found that $\mathrm{HdhCu} / \mathrm{ZnSOD}$ did not change the activity of normal L929 cells. Furthermore, a cell peroxidation damage model of L929 cells was established. $\mathrm{H}_{2} \mathrm{O}_{2}$ is a stable ROS, which has previously been shown to inhibit the growth of L929 cells, resulting in their apoptosis (Ou et al. 2011; Shirato et al. 2016). Our results showed that $\mathrm{HdhCu} / \mathrm{Zn}$-SOD had a protective effect against hydrogen peroxide-induced cell damage, which may have been due to the ability of SOD to scavenge oxygen free radicals, whose production is stimulated by peroxide damage, in L929 cells, thus reducing the oxidative damage to cells. Similarly, Xu et al. (2010) carried out ethanol damage simulation experiments on cell models, which revealed that $\mathrm{Cu} / \mathrm{Zn}$-SOD from Cristaria plicata could protect $\mathrm{L} 02$ hepatocytes from ethanol damage.

An assessment of the recombinant $\mathrm{HdhCu} / \mathrm{ZnSOD}$ protein showed that it did not cause hemolysis of horse erythrocytes, indicating that the enzyme was safe for cells. However, more comprehensive safety and efficacy evaluation is needed to future explore its application in cosmetic and medicine.

\section{Conclusion}

The heterologous expression of $\mathrm{HdhCu} / \mathrm{Zn}-\mathrm{SOD}$ in $P$. pastoris and the antioxidant activity of this enzyme are reported for the first time. Recombinant $\mathrm{HdhCu} / \mathrm{Zn}$-SOD showed high enzyme activity and good antioxidant activity, as well as protective effects against $\mathrm{H}_{2} \mathrm{O}_{2}$-induced cellular damage. This protein is stable and safe at the cellular level, demonstrating its potential as a natural antioxidant agent for use in medicine and cosmetics.

Acknowledgements This study was funded by the National Natural Science Foundation of Fujian Province (No. 2017J01041); the National Marine Public Welfare Research Project of China (No. 201405016); and the Open Program of the Key Laboratory of Cultivation and High-value Utilization of Marine Organisms in Fujian Province (No. 2015fjscq04).

\section{Compliance with ethical standards}

Conflict of interest The authors declare that they have no conflict of interest.

Open Access This article is licensed under a Creative Commons Attribution 4.0 International License, which permits use, sharing, adaptation, distribution and reproduction in any medium or format, as long as you give appropriate credit to the original author(s) and the source, provide a link to the Creative Commons licence, and indicate if changes were made. The images or other third party material in this article are included in the article's Creative Commons licence, unless indicated otherwise in a credit line to the material. If material is not included in the article's Creative Commons licence and your intended use is not permitted by statutory regulation or exceeds the permitted use, you will need to obtain permission directly from the copyright holder. To view a copy of this licence, visit http://creativecommons.org/licenses/by/4.0/.

\section{References}

Achuba FI (2002) Superoxide dismutase and lipid peroxidation levels in fish from the Ethiope River in southern Nigeria. Bull Environ Contam Toxicol 69(6):892-899

Ahmad M, Hirz M, Pichler H, Schwab H (2014) Protein expression in Pichia pastoris: recent achievements and perspectives for 
heterologous protein production. Appl Microbiol Biotechnol 98(12):5301-5317

Anju A, Jeswin J, Thomas PC, Paulton MP, Vijayan KK (2013) Molecular cloning, characterization and expression analysis of cytoplasmic $\mathrm{Cu} / \mathrm{Zn}$-superoxid dismutase (SOD) from pearl oyster Pinctada fucata. Fish Shellfish Immuno 34:946-950

Bao Y, Li L, Wu Q, Zhang G (2009a) Cloning, characterization, and expression analysis of extracellular copper/zinc superoxide dismutase gene from bay scallop Argopecten irradians. Fish Shellfish Immunol 27(1):17-25

Bao Y, Li L, Xu F, Zhang G (2009b) Intracellular copper/zinc superoxide dismutase from bay scallop Argopecten irradians: its gene structure, mRNA expression and recombinant protein. Fish Shellfish Immunol 27(2):210-220

Bao Y, Li L, Zhang G (2008) The manganese superoxide dismutase gene in bay scallop Argopecten irradians: cloning, 3D modelling and mRNA expression. Fish Shellfish Immunol 25(4):425-432

Cai L, Wu X, Zhang Y, Li X, Ma S, Li J (2015) Purification and characterization of three antioxidant peptides from protein hydrolysate of grass carp (Ctenopharyngodon idella) skin. J Funct Foods $16: 234-242$

Che M, Wang R, Li X, Wang HY, Zheng XFS (2016) Expanding roles of superoxide dismutases in cell regulation and cancer. Drug Discov Today 21(1):143-149

De Zoysa M, Ekanayake PM, Kang HS, Lee J, Jee Y, Lee YH, Kim SJ (2009) Disk Abalone, Haliotis discus discus, CuZn-Superoxide Dismutase cDNA and its Transcriptional Induction by Aroclor 1254. J World Aquaculture Soc 40:643-658

Finkel T, Holbrook NJ (2000) Oxidants, oxidative stress and the biology of ageing. Nature 408(6809):239-247

Fukai T, Ushio-Fukai M (2011) Superoxide dismutases: role in redox signaling, vascular function, and diseases. Antioxidants Redox Signaling 15(6): 1583-1606

Gao X, He C, Liu H, Li H, Zhu D, Cai S, Xia Y, Wang Y, Yu Z (2012) Intracellular $\mathrm{Cu} / \mathrm{Zn}$ superoxide dismutase $(\mathrm{Cu} / \mathrm{Zn}-\mathrm{SOD})$ from hard clam Meretrix meretrix: its cDNA cloning, mRNA expression and enzyme activity. Mol Biol Rep 39(12):10713-10722

Genestra M (2007) Oxyl radicals, redox-sensitive signalling cascades and antioxidants. Cell Signal 19(9):1807-1819

Han J, Lu Y, Zheng H, Liu H, Deng H, Zhang B (2016) Differential expression of $\mathrm{CuZnSOD}$ gene under low temperature stress in noble scallop Chlamys nobilis with different carotenoid content. Fish Shellfish Immunol 54:30-39

Hong-Duk Y, Eun-Ja K, Jung-Hye R, HAH YC, Sa-Ouk K (1996) A novel nickel-containing superoxide dismutase from Streptomyces spp. Biochem J 318(3):889-896

Hsieh SL, Ruan YH, Li YC, Hsieh PS, Hu CH, Kuo CM (2008) Immune and physiological responses in Pacific white shrimp (Penaeus vannamei) to Vibrio alginolyticus. Aquaculture 275(1-4):335-341

Huang WB, Ren HL, Gopalakrishnan S, Xu DD, Qiao K, Wang KJ (2010) First molecular cloning of a molluscan caspase from variously colored abalone (Haliotis diversicolor) and gene expression analysis with bacterial challenge. Fish Shellfish Immunol 28:587-595

Kim BM, Rhee JS, Park GS, Lee J, Lee YM, Lee JS (2011) Cu/Znand $\mathrm{Mn}$-superoxide dismutase (SOD) from the copepod Tigriopus japonicus: molecular cloning and expression in response to environmental pollutants. Chemosphere 84(10):1467-1475

Kim EJ, Kim HP, Hah YC, Roe JH (1996) Differential expression of superoxide dismutases containing $\mathrm{Ni}$ and $\mathrm{Fe} / \mathrm{Zn}$ in Streptomyces coelicolor. Eur J Biochem 241(1):178-185

Lee SY, Nam YK (2016) Evaluation of reference genes for RT-qPCR study in abalone Haliotis discus hannai during heavy metal overload stress. Fish Aquat Sci 19(1):21
Lin YC, Vaseeharan B, Chen JC (2008) Identification of the extracellular copper-zinc superoxide dismutase (ecCuZnSOD) gene of the mud crab Scylla serrata and its expression following $\beta$-glucan and peptidoglycan injections. Molecular Immunol 45(5):1346-1355

Liu HP, Chen FY, Gopalakrishnan S, Qiao K, Bo J, Wang KJ (2010) Antioxidant enzymes from the crab Scylla paramamosain: gene cloning and gene/protein expression profiles against LPS challenge. Fish Shellfish Immunol 28(5-6):862-871

Li HF, Sun XF, Cai ZH, Cai GP, Xing KZ (2010) Identification and analysis of a $\mathrm{Cu} / \mathrm{Zn}$ superoxide dismutase from Haliotis diversicolor supertexta with abalone juvenile detached syndrome. $\mathrm{J}$ Inverterbr Pathol 103:116-123

Macauley-Patrick S, Fazenda ML, McNeil B, Harvey LM (2005) Heterologous protein production using the Pichia pastoris expression system. Yeast 22(4):249-270

Melidou M, Riganakos K, Galaris D (2005) Protection against nuclear DNA damage offered by flavonoids in cells exposed to hydrogen peroxide: the role of iron chelation. Free Radic Biol Med 39(12):1591-1600

Nikapitiya C, De Zoysa M, Lee J (2008) Molecular characterization and gene expression analysis of a pattern recognition protein from disk abalone, Haliotis discus discus. Fish Shellfish Immuno 25:638-647

Ou Y, Zheng S, Lin L, Li Q (2011) C-phycocyanin from Spirulina maxima protects hepatocytes against oxidative damage induced by $\mathrm{H}_{2} \mathrm{O}_{2}$ in vitro. Biomedicine \& Preventive Nutrition 1:8-11

Oyanagui Y (1984) Reevaluation of assay methods and establishment of kit for superoxide dismutase activity. Anal Biochem 142(2):290-296

Peng H, Liu HP, Chen B, Hao H, Wang KJ (2012) Optimized production of scygonadin in Pichia pastoris and analysis of its antimicrobial and antiviral activities. Protein Expr Purif 82(1):37-44

Penicaud V, Lacoue-Labarthe T, Bustamante P (2017) Metal bioaccumulation and detoxification processes in cephalopods: a review. Environ Res 155:123-133

Qiao K, Xu WF, Chen HY, Peng H, Zhang YQ, Huang WS, Wang SP, An Z, Shan ZG, Chen FY (2016) A new antimicrobial peptide SCY2 identified in Scylla paramamosain exerting a potential role of reproductive immunity. Fish Shellfish Immunol 51:251-262

Ren HL, Xu DD, Gopalakrishnan S, Qiao K, Huang WB, Wang KJ (2009) Gene cloning of a sigma class glutathione S-transferase from abalone (Haliotis diversicolor) and expression analysis upon bacterial challenge. Dev Comp Immunol 33:980-990

Ren X, Wang Z, Gao B, Liu P, Li J (2017) Toxic responses of swimming crab (Portunus trituberculatus) larvae exposed to environmentally realistic concentrations of oxytetracycline. Chemosphere 173:563-571

Sargis RM, Subbaiah PV (2006) Protection of membrane cholesterol by sphingomyelin against free radical-mediated oxidation. Free Radic Biol Med 40(12):2092-2102. https://doi.org/10.1016/j.freer adbiomed.2006.02.005

Sánchez-Venegas JR, Navarrete A, Dinamarca J, Ramírez LAB, Moraga AG, Gidekel M (2009) Cloning and constitutive expression of Deschampsia antarctica $\mathrm{Cu} / \mathrm{Zn}$ superoxide dismutase in Pichia pastoris. BMC Res Notes 2(1):207

Shirato K, Takanari J, Ogasawara J, Sakurai T, Imaizumi K, Ohno H, Kizaki T (2016) Enzyme-treated asparagus extract attenuates hydrogen peroxide-induced matrix metalloproteinase- 9 expression in murine skin fibroblast L929 cells. Nat Prod Commun 11:677-680

Smith RAJ, Kelso GF, Blaikie FH, Porteous CM, Ledgerwood EC, Hughes G, James AM, Ross MF, Asin-Cayuela J, Cochemé HM, Filipovska A, Murphy MP (2003) Using mitochondria-targeted molecules to study mitochondrial radical production and its consequences. Biochem Soc Trans 31(6):1295-1299 
Stadtman ER, Levine RL (2003) Free radical-mediated oxidation of free amino acids and amino acid residues in proteins. Amino Acids 25(3-4):207-218

Wang Q, Yuan Z, Wu H, Liu F, Zhao J (2013) Molecular characterization of a manganese superoxide dismutase and copper/zinc superoxide dismutase from the mussel Mytilus galloprovincialis. Fish Shellfish Immunol 34(5):1345-1351

Wigham GD (1976) Feeding and digestion in the marine prosobranch Rissoa parva (Da Costa). J Molluscan Stud 42(1):74-94

Wu W, Mak C, Ko R (2008) Cloning and differential expression of manganese superoxide dismutase (Mn-SOD) of Trichinella pseudospiralis. Parasitol Res 102(2):251-258

Wu Y, Shi D, Chen X, Wang L, Ying Y, Ma C, Xi X, Zhou M, Chen T, Shaw C (2019) A novel bradykinin-related peptide, RVA-Thr6$\mathrm{BK}$, from the skin secretion of the Hejiang frog; Ordorrana hejiangensis: effects of mammalian isolated smooth muscle. Toxins 11(7):376

Xu HH, Ma H, Hu BQ, Lowrie DB, Fan XY, Wen CG (2010) Molecular cloning, identification and functional characterization of a novel intracellular $\mathrm{Cu}-\mathrm{Zn}$ superoxide dismutase from the freshwater mussel Cristaria plicata. Fish Shellfish Immunol 29(4):615-622

Zeng L, Xia T, Hu W, Chen S, Chi S, Lei Y, Liu Z (2018) Visualizing the regulation of hydroxyl radical level by superoxide dismutase via a specific molecular probe. Anal Chem 90(2):1317-1324

Zheng L, Wu B, Liu Z, Tian J, Yu T, Zhou L, Sun X, Yang A (2015) A manganese superoxide dismutase (MnSOD) from ark shell, Scapharca broughtonii: molecular characterization, expression and immune activity analysis. Fish Shellfish Immunol 45(2):656-665

Publisher's Note Springer Nature remains neutral with regard to jurisdictional claims in published maps and institutional affiliations. 